\title{
Gender-Based Violence and Christianity: Catholic Prevention of Divorce Traps Women in an Abusive Marriage
}

\author{
John Simister ${ }^{1}$, Grażyna Kowalewska² \\ ${ }^{1}$ Accounting, Finance \& Economics Department, Manchester Metropolitan University, Manchester, UK \\ ${ }^{2}$ Faculty of Economics, University of Warmia and Mazury in Olsztyn, Olsztyn, Poland \\ Email: j.g.simister@mmu.ac.uk
}

How to cite this paper: Simister, J., \& Kowalewska, G. (2016). Gender-Based Violence and Christianity: Catholic Prevention of Divorce Traps Women in an Abusive Marriage. Psychology, 7, 1624-1644. http://dx.doi.org/10.4236/psych.2016.713155

Received: October 11, 2016

Accepted: November 11, 2016

Published: November 14, 2016

Copyright $\odot 2016$ by authors and Scientific Research Publishing Inc. This work is licensed under the Creative Commons Attribution International License (CC BY 4.0).

http://creativecommons.org/licenses/by/4.0/ (c) (i) Open Access

\begin{abstract}
This paper reports evidence on Gender-Based Violence (GBV), violence against women by husband or male partner, based on household surveys from many countries. A woman's risk of experiencing domestic violence varies, within a country and between countries, for many reasons. This paper focuses on religion: in particular, comparing Catholics with Protestants. It reports evidence that Catholic women have a higher risk of GBV than Protestant women. A possible explanation for this higher risk is investigated: the ban on divorce by the Catholic Church. Household surveys confirm that Catholics are less likely than Protestants to divorce. Divorce is a possible escape-route for a woman abused by her husband; preventing divorce keeps many women trapped in marriage to a violent husband.
\end{abstract}

\section{Keywords}

Gender-Based Violence, Catholic, Protestant, Divorce

\section{Introduction}

Domestic violence is a global problem (WHO, 2013); victims of domestic violence, regardless of geographical and cultural differences, are mostly children and women rather than men. This paper focuses on violence against women by their husband or male partner, often called Gender-Based Violence (GBV); other kinds of domestic violence, such as violence against men or children, are beyond the scope of this paper. Academics can help activists and politicians reduce GBV.

Risk of GBV depends on many factors, such as absence or existence of love between spouses; education, the political system, the history of each country, and the strength of 
feminist movements. There is insufficient space to discuss all these factors here. Similarly, this paper cannot explore all possible influences on whether a woman experiencing GBV will divorce her husband: her choice is influenced by factors such as whether she has children; if she has sufficient income; whether her family would accept her, if she divorced; ethnicity/culture; and education.

The main hypothesis of this paper is that there is a difference between Protestant Christianity, which generally advocates a person should make his/her own decisions about morality; and Catholicism, which is more "Patriarchal". In particular, Catholic women may be more likely than Protestant women, to accept GBV. Acceptance of GBV may be related to the Catholic Church banning divorce.

\section{Literature Review}

\subsection{What Is GBV?}

Domestic violence includes a husband attacking his wife, a wife attacking her husband, and parents attacking children. This paper focuses on Gender-Based Violence (GBV), in which a man threatens/attacks his wife (or unmarried female partner), in order to control her (Ellsberg \& Heise, 2005). National Population Commission \& ICF Macro (2009: p. 261) defines GBV as an act of violence likely to cause physical, sexual, or psychological harm. GBV includes physical violence; emotional damage (e.g. humiliation or intimidation); sexual abuse; economic dependence (e.g. husband controlling the family income); and social isolation (e.g. preventing his wife from contacting her relatives). GBV "saps women's energy, compromises their physical and mental health, and erodes their self-esteem. In addition to causing injury, violence increases women's long-term risk of a number of other health problems, including chronic pain, physical disability, drug and alcohol abuse, and depression" (Ellsberg \& Heise, 2005). GBV may make a woman less effective, in employment and caring for her children (Slabu, 2014: pp. 56-57).

\subsection{GBV Prevalence}

It seems likely that domestic violence occurred for thousands of years, but we have limited data. Targeted research on family violence started in the twentieth century; violence against women as a social problem was isolated in the 1960s by feminist organizations seeking women's liberation. Domestic violence is a problem everywhere: "35\% of women worldwide have experienced either physical and/or sexual intimate partner violence or non-partner sexual violence $[\ldots]$ most of this violence is intimate partner violence. Worldwide, almost one third (30\%) of all women who have been in a relationship have experienced physical and/or sexual violence by their intimate partner" (WHO, 2013: p. 2). And "some national violence studies show that up to 70 per cent of women have experienced physical and/or sexual violence in their lifetime from an intimate partner" (UN Women, 2016).

There are disagreements on how to research domestic violence. Surveys underestimate GBV: "because of the sensitivity of the subject, violence against women is almost 
universally under-reported" (Watts \& Zimmerman, 2002: p. 1232), partly because victims fear further punishment if they tell anyone about GBV. Under-reporting is more extreme in crime data (Slabu, 2014: p. 50): many crimes go unpunished from lack of evidence. GBV estimates in this paper should be interpreted with care-real GBV prevalence rates are much higher.

\subsection{Why Does GBV Happen?}

GBV occurs most often at home, and may be due to uneven relations between family members: a man uses GBV to make his partner afraid of physical/emotional harm. Several researchers found GBV occurs more often if a woman's occupational status is higher than her husband's status (Anderson, 1997: p. 657). Knoblock (2008: p. 96) claims GBV is caused by low self-esteem among violent men. "Intimate partner violence is integrally linked to ideas of male superiority over women. These are manifest in different ways in different societies, but violence is usually used to create and enforce gender hierarchy and punish transgressions; to resolve relationship conflict; and to seek resolution of crisis of masculinity by providing an (often transient) sense of powerfulness" (Burazeri et al., 2005).

Domestic violence causes can be divided into four risk factors: individual (including personality traits); family; environmental; and cultural/moral-cultural patterns sometimes condone GBV. Lew-Starowicz (1992: pp. 50-52) classifies causes of violence into three types: biological (e.g. testosterone, central nervous system disorders, \& chromosomal abnormalities); psychological (e.g. childhood experiences, stress, \& alcohol); and cultural (e.g. television, social isolation, \& male-dominated cultures).

There are theories on why many women remain with a violent husband, such as the "battered woman syndrome", incorporating "learned helplessness" (women become passive to avoid further violence); "cycle of violence" (a violent man persuades his wife that he regrets his violence); and "Post Traumatic Stress Disorder" (a traumatised woman is less able to act) (Dutton, 2009). Divorce may be more traumatic for Christians than for non-Christians: marriage is "made sacred by God" (Webb, 2008: p. 11), so a divorcing woman may feel guilt. Among Christians, "When problems such as domestic violence occur, a woman may be encouraged to wait, pray, and live a pious life to fulfil her supportive role as a helpmate to her husband" (Foss \& Warnke, 2003: p. 18). A Christian woman might feel she "deserves" to be punished-perhaps because of Eve's behaviour in the Garden of Eden (Foss \& Warnke, 2003: p. 19); it isn't clear if Catholics are more or less prone to such ideas than Protestants.

There are many attempts to prevent GBV. Cooper et al. (2013: p. 370) discuss alternatives, including the (feminist) Duluth intervention-associated with a "psychoeducational model" - which sees GBV as due to some men internalising patriarchal ideology; their solution seeks to move violent men from authoritarian to egalitarian relationships. The "Cognitive Behavioural Model" considers some men to have errors in their thinking, and seeks solutions such as skills training \& anger management (Cooper et al., 2013: p. 370). 


\subsection{Patriarchy and GBV}

Many writers consider GBV central to maintaining patriarchy (control of a group by one man). Patriarchy may have begun before Christianity-perhaps thousands of years ago (Fox, 2002). In Feudal-era Europe, paternal authority over his family was almost unlimited (Duby, 1999: p. 226); Roman law was reinforced by the 1804 Napoleonic Code and English case law. "Since Biblical times women have been beaten into submission and considered to be "property" by their men [...] at one time in both American and British history, the law actually allowed men to beat their wives with a "stick no bigger than his thumb" (Hanson, 1993: pp. 19-20).

Foss \& Warnke (2003: p. 20) claim "research connects firm commitment to patriarchal ideology with a woman's willingness to remain in an abusive relationship [...] she may question her ability to leave her husband and may have few social supports for separating". Bystydzienski (2001: p. 509) claims patriarchy was reinforced by cultural traditions emphasizing women's subordination to men; and by the Catholic Church. Patriarchal churches may support patriarchy within families: Catholic domination of Europe caused GBV to be seen as a private family issue (Wojnicka, 2015: p. 41). Fundamentalist (evangelical) Protestant groups are similar to the Catholic Church, in supporting patriarchy (Foss \& Warnke, 2003: p. 15).

\subsection{Divorce}

Divorce can provide physical \& psychological safety, by allowing a woman (and her children) to leave a violent marriage; "In countries where divorce is more accepted and widely practiced, women's position within marriages is better" (Yodanis, 2005: pp. 655-656). However, it might harm some women if divorce were easier, by making it easier for a man to abandon his wife \& children. Many women are responsible for children, but have fewer opportunities than men to obtain well-paid jobs; and women are more likely than men to experience domestic violence (Ellsberg \& Heise, 2005)-so a man can threaten divorce to control his wife. Female earnings reduce a woman's risk of experiencing GBV, by giving her more choice to leave a violent man (Bowlus \& Seitz, 2006; Aizer, 2010: p. 1847).

A perspective associated with Catholicism and some evangelical groups, is that marriage is indissoluble-justified by Luke (16: 18): "Anyone who divorces his wife and marries another woman commits adultery, and the man who marries a divorced woman commits adultery" (Bible Hub, 2015; Bible quotes in this paper use the "New International Version"). Some Christians consider re-marriage a sin; a divorcee should remain single for the rest of their life. But Matthew (5:32) states "anyone who divorces his wife, except for sexual immorality, makes her the victim of adultery" (Bible Hub, 2015), implying a person may re-marry if their spouse was unfaithful. Divorcing a non-Christian is permitted: Paul's first Corinthians letter (7: 12-5) states "If any brother has a wife who is not a believer and she is willing to live with him, he must not divorce her. And if a woman has a husband who is not a believer and he is willing to live with her, she must not divorce him. [...] But if the unbeliever leaves, let it be so. The brother or the sister is 
not bound in such circumstances" (Bible Hub, 2015). Many charismatic churches permit divorce after conversion to Christianity: "if anyone is in Christ, the new creation has come: the old has gone, the new is here!" (Corinthians 2, 5: 17) (Bible Hub, 2015). Some Protestant Churches emphasise God's love, seeing divorce as the person's own decision-if divorce \& re-marriage is a sin requiring repentance, other Christians can forgive a divorcee and support re-marriage.

\subsection{Is Divorce Less Frequent among Catholics?}

The Catholic Church prevents divorce (Webb, 2008: p. 21; Lehrer et al., 2009): "The remarriage of persons divorced from a living, lawful spouse contravenes the plan and law of God" (Holy See, 1993: p. 1665). Marks (2006) claims religion affects marriage in three ways: religious beliefs, religious practices, and religious communities. Hence, "divorce represents a situation in which religion may serve as either a form of social support or social control. Some divorcees may find their religion to be a source of solace and comfort, while others may experience stigma from their religious community as a result of their divorced status" (Webb, 2008: p. 4). For example, "the single most unifying cultural factor in Latin America is the Catholic faith-its belief-system woven deeply into the history and traditions of the region" (Edgerton \& Sotirova, 2011: p. 36). Catholicism also affects divorce indirectly: divorce is illegal in some Catholic countries, such as the Philippines (Yodanis, 2005: p. 650). Sharp (2009) uses the term "symbolic entrapment" to explain why some conservative Christian women (including Catholics) stay in an abusive marriage because they consider divorce sinful. Some evangelical Christian denominations also discourage divorce: among devout fundamentalist Protestants, "women are likely to believe that marriage must be preserved at any cost" (Foss \& Warnke, 2003: p. 19). Ellison, Wolfinger \& Ramos-Wada (2011) claimed "evangelical Protestants who attend church regularly have almost uniformly more conservative attitudes than do equally observant Catholics"; similar views are expressed by Edgerton \& Sotirova (2011: p. 39).

\subsection{Is GBV More Common among Catholics?}

Bystydzienski (2001: p. 502) wrote "the Catholic church has supported traditional roles for women and has taught them to accept their fate and to be martyrs for their nation and the family". The Catholic Church adversely affected GBV victims in Chile (Lehrer et al., 2009: p. 2). Catholicism in Papua New Guinea encouraged female subordination: "a wife should not leave her husband, even if his violence persists unabated" (Jolly, 2012: p. 17). The 2011 DHS Uganda survey found physical violence in the past 12 months was experienced more among Catholic women than Protestant women (Uganda Bureau of Statistics \& ICF International Inc, 2012: p. 242). Similarly, in the 2013 DHS Nigeria survey, "The highest proportion of women who have experienced physical, sexual, or emotional violence is found among Catholics (40 percent), followed by other Christians and traditionalists" (National Population Commission \& ICF International, 2014: p. 315). However, Brinkerhoff et al. (1992: p. 15) found religious denomi- 
nation not significantly related to GBV risk, in Canada. Foss \& Warnke (2003: p. 15) analysed fundamentalist Protestant Church groups-reporting that among GBV victims, "gender, family process and structure, and culture may intersect to prohibit or facilitate healthy life choices. Family violence and tolerance for family violence tend to be passed down through generations".

\subsection{Could Divorce Explain Higher GBV Prevalence among Catholics?}

A woman experiencing GBV may see divorce as a way to escape violence. If Catholics have higher GBV risk than Protestants, this increased risk may be due to Catholic women staying with a violent husband. This paper studies members of the Roman Catholic Church (referred to as “Catholics”), contrasted with 'Protestants' (members of other Christian denominations). Where possible, data on evangelical Protestants are separated from non-evangelical Protestants.

This paper tests three hypotheses. The first hypothesis is that Catholics are less likely than (non-evangelical) Protestants, to divorce. The second hypothesis is that GBV is a reason why some women seek divorce. The third hypothesis is that many Catholic women remain trapped in a violent marriage, due to the Catholic Church's opposition to divorce.

\section{Methods}

This paper analyses quantitative evidence, acknowledging that topics studied in this paper (such as GBV) are subjective-for example, a question may be distorted when translating a questionnaire to another language. Watts \& Zimmerman (2002) state "variations in the willingness of respondents to disclose experiences of violence and differences in the populations in which the studies are done make cross-country and cross-study comparison difficult". Ellsberg \& Heise (2005) claim "For cross-cultural comparisons, aggregating emotional, sexual, and physical abuse in a single domestic violence figure is likely to lead to confusion [...] Combining these categories may reduce the credibility of the findings, as many policy makers consider emotional abuse to be less severe than the other types of violence".

The largest samples used for this paper are from "Demographic and Health Surveys" (DHS), part-funded by USAID; the authors consider DHS the best GBV data source. Each DHS survey has a large sample size, and is nationally-representative of the country. Not all DHS surveys include GBV data; the authors attempted to analyse data for all countries with GBV data in 2014 (on the DHS website). DHS data in this paper were collected between 2000 and 2013.

EuroBarometer (EB) is a series of household surveys, which mainly investigate attitudes to the European Union (EU)_carried out several times per year since early 1970s, funded by the European Commission. EB investigated more countries, as EU expanded (some countries outside EU are surveyed). Each EB survey randomly samples households, giving a nationally-representative sample in every country studied (European Commission, 2008). Interviews are conducted face-to-face, sampling about a 
thousand people per country in each survey. EB data are downloaded from the Gesellschaft Sozialwissenschaftlicher Infrastruktureinrichtungen website (GESIS, 2015).

This paper also reports evidence from World Values Survey (WVS) and European Values Survey (EVS) household surveys. WVS and EVS are produced by a global network of social scientists, who study changing values and their impact on social and political life (WVS, 2015a). EVS investigates attitudes in Europe, exploring moral \& social values underlying European social and political institutions; their first survey was in 1981 (EVS, 2011). EVS and WVS surveys use random sampling, to give nationallyrepresentative samples of each country they study. Authors downloaded data for all available years from WVS (2015b) and EVS (2011). For this paper, WVS \& EVS data are combined where possible.

A fourth survey set is International Social Survey Programme (ISSP), which evolved from collaboration between the German ALLBUS survey (from 1980) and General Social Survey in USA (from 1972). Other organisations joined ISSP: for example, Social and Community Planning Research added "British Social Attitudes" surveys. These organisations harmonised their questionnaires (ISSP, 2015). ISSP surveys from 1988 are used for this paper, from GESIS (2015).

Using weights to correct for known imperfections in sampling has advantages; but they often aim to produce a representative sample within a country-whereas this paper combines data between countries. ISSP (2015) warn "STRONGLY recommend using weights only after careful consideration"; for this paper, data are unweighted for all surveys. In all surveys used for this paper, only adults are interviewed; but age-ranges vary. DHS surveys used in this paper interviewed women from 15 - 49 years old, except Nigeria 1999 which interviewed ages 10 - 49. Among DHS surveys, only female respondents are studied for this paper (in most DHS surveys, only women are asked about GBV); the other studies include approximately equal numbers of male \& female respondents.

For some surveys, the authors assess the likelihood of divorce using the "divorce ratio": the ratio between the number of people who are divorced, to the number married at the time of interview. This is an imperfect measure, because some respondents describing themselves as married may have previously divorced (few surveys studied for this paper ask about earlier divorce or re-marriage; this reduces the sample-size in Table 3). For the "divorce ratio", the authors exclude respondents who are neither married nor divorced (single, cohabiting, widowed, or separated).

DHS use a modified version of "Conflict Tactics Scale" (National Population Commission \& ICF Macro, 2009: p. 271), including several types of GBV; the list varies slightly between surveys (e.g. "pulling hair" is sometimes included). A typical DHS questionnaire is the 2008 Nigeria survey, which asked women:

Question 1305: Did your (last) husband/partner ever.

1) say or do something to humiliate you in front of others?

2) threaten to hurt or harm you or someone close to you?

3) insult you or make you feel bad about yourself? 
Question 1306: "Did your (last) husbandl partner ever do any of the following things to you:

1) slap you?

2) twist your arm or pull your hair?

3) push you, shake you, or throw something at you?

4) punch you with his fist or with something that could hurt you?

5) kick you, drag you or beat you up?

6) try to choke you or burn you on purpose?

7) threaten or attack you with a knife, gun, or other weapon?

8) physically force you to have sexual intercourse with him even when you did not want to?

9) force you to perform any sexual acts you did not want to?"

(National Population Commission \& ICF Macro, 2009: pp. 594-595).

For each part of questions 1305 and 1306, women said "yes" or "no"; then, they were asked how often each type of GBV happened in the 12 months before the interview. Data on sexual violence are included in DHS, but it is debatable if sexual violence is part of GBV, or a separate problem (Simister, 2012). For each type of GBV, the authors gave a score of zero for "not experienced"; 4 for "yes, sometimes"; 7 for "yes" [frequency unspecified]; or 10 for "yes, frequently" (scores 4, 7, and 10 are arbitrary). If a woman experienced all twelve GBV forms frequently, she would score $10 \times 12=120$ (the highest score calculated is 110).

The list of religions varies between surveys. For example, the 2008 Nigeria DHS survey asked "What is your religion? Catholic, other Christian, Islam, Traditional, or other" (National Population Commission \& ICF Macro, 2009: p. 529). Some surveys combine all Christians into one category (such surveys are not used, because this paper contrasts Catholics with Protestants). The authors classify "Seventh Day Adventists" and "Jehovah's Witnesses" as Protestant; some surveys ask respondents if they are Catholic or Protestant, so "Protestants" may include other groups such as Mormons.

The authors attempted to analyse evangelical Protestants separately from other Protestants, but this is impossible for some surveys. ISSP classify evangelical Protestants separately from 1988 to 2001, but group evangelicals with Protestants in later ISSP surveys; the authors exclude evangelicals before 2002, but retain evangelicals with other Protestants from 2002. The definition of evangelical may vary between surveys (some respondents call themselves "evangelical Christian" without clarification). ISSP classify Baptist, Lutheran, Pentecostal, Presbyterian, United Reform Church, Wesleyan, and "born again" Christians as evangelical. Orthodox Christianity has similarities with Catholicism; Orthodox Christians are excluded from analysis, because there are relatively few Orthodox respondents in surveys analysed for this paper. Non-Christians and atheists are excluded from analysis.

This paper combines many countries in one chart; combining countries conceals differences between countries, but there are too many countries to produce a chart for each country. SPSS syntax for this paper is available from the authors on request. 


\section{Results}

The first issue is whether divorce is less frequent among Catholics than Protestants. Some Christians are more religious than others; Figure 1 shows the fraction of respondents who are divorced, depending on church attendance. The two lines represent respondents calling themselves Catholic, or Protestant (including evangelical Protestants). Figure 1 combines data from ten Eurobarometer surveys, in 32 European countries, in 1996, 1998, 2005, 2006 \& 2010; sample sizes are in Table A1. The authors divide the number of divorcees by number of married people, to produce a ratio \{married to divorced\} on the vertical axis. Respondents who are widowed, separated, cohabiting or never-married people are excluded from Figure 1.

Figure 1 indicates that divorce is less frequent among Catholics than Protestants. The tendency for Catholics to have a lower divorce ratio becomes stronger as we go from left (interviewees who rarely attend church) to right (interviewees attending more than once per week). Among Catholics who don't attend church, there are about 0.17 divorced people for every married person; whereas for Catholics attending more than once per week, there are about 0.05 divorced people for every married person. Figure 1 is consistent with the idea that the Catholic Church's ban on divorce influences

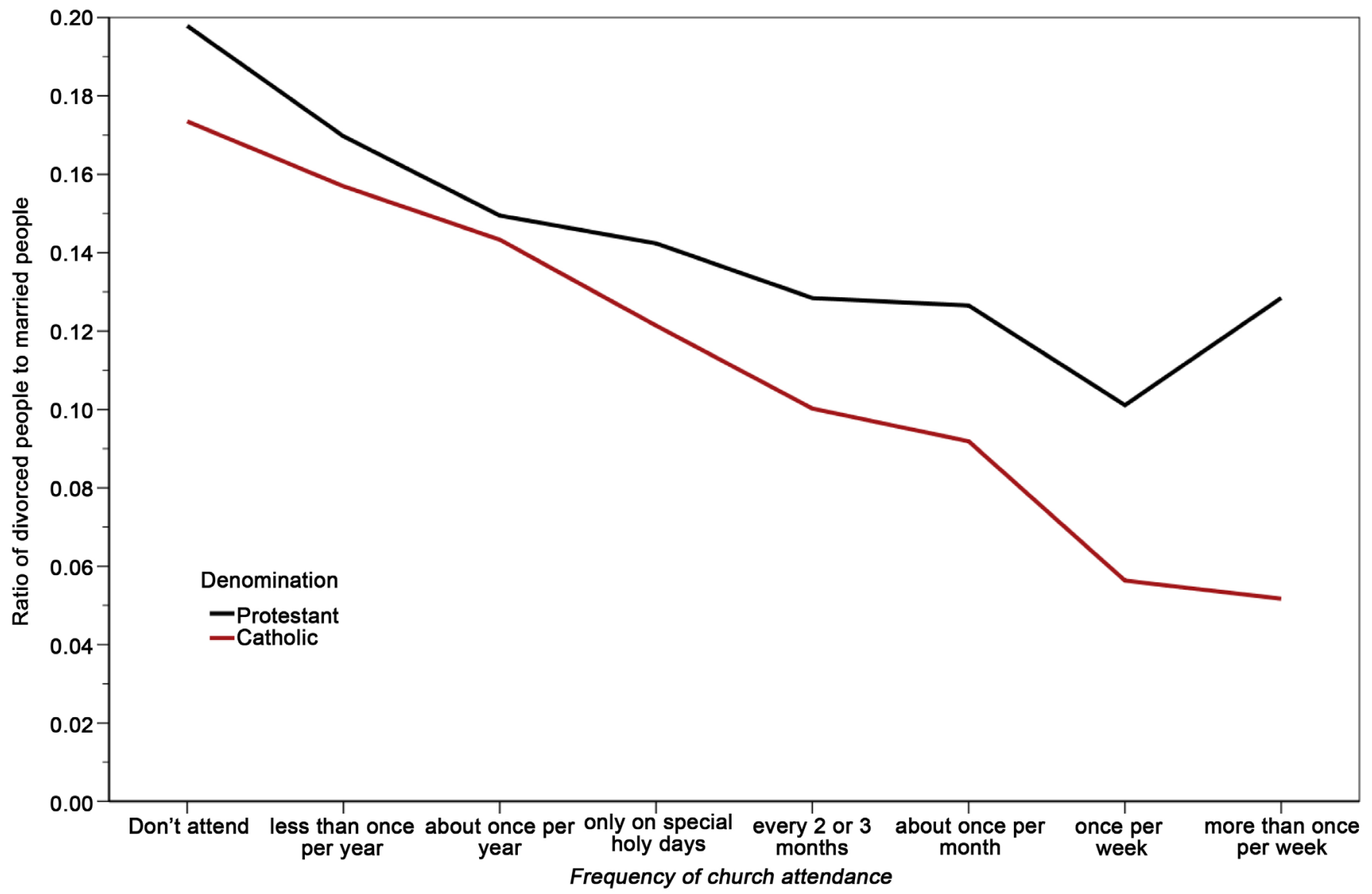

Figure 1. Divorce ratio, by frequency of church attendance and denomination. Source: EB surveys 46.1, 50.0, 63.1, 63.4, 64.3, 65.1, 65.2, $65.3,66.1 \& 73.1$ (authors' analysis). 
observant Catholics.

Figure 2 is similar to Figure 1 (Figure 2 uses ISSP data, whereas Figure 1 uses EB), using data from different countries (see Table A1). Labels on the horizontal axis show church attendance, but ISSP use different categories to EB. Figure 2 shows Catholics tend to have lower divorce-rates than Protestants. Divorce-rates in Figure 1 are higher than Figure 2, perhaps because Figure 1 uses European data-whereas ISSP have more global coverage.

Figure 3 is based on EVS from 1981 to 2009 and WVS from 1981 to 2014; countries covered are listed in Table A1. Figure 3 is similar to Figure 1 and Figure 2, with the addition of a line for evangelical Christians (which is similar to non-evangelical Protestants). Figures 1-3 may be influenced by legislation preventing divorce (e.g. the Philippines). However, divorce laws cannot explain the tendency for lines in these charts to fall from left to right: people attending church more often are less likely to divorce. Practising Catholics are less likely to be divorced than non-practising Catholics. Perhaps many Catholics feel forced to accept GBV, because the Catholic Church forbids divorce. If divorce is a way to escape violence, then Catholics' lower acceptance of divorce (implied by Figures 1-3) may increase the risk of GBV among Catholics.

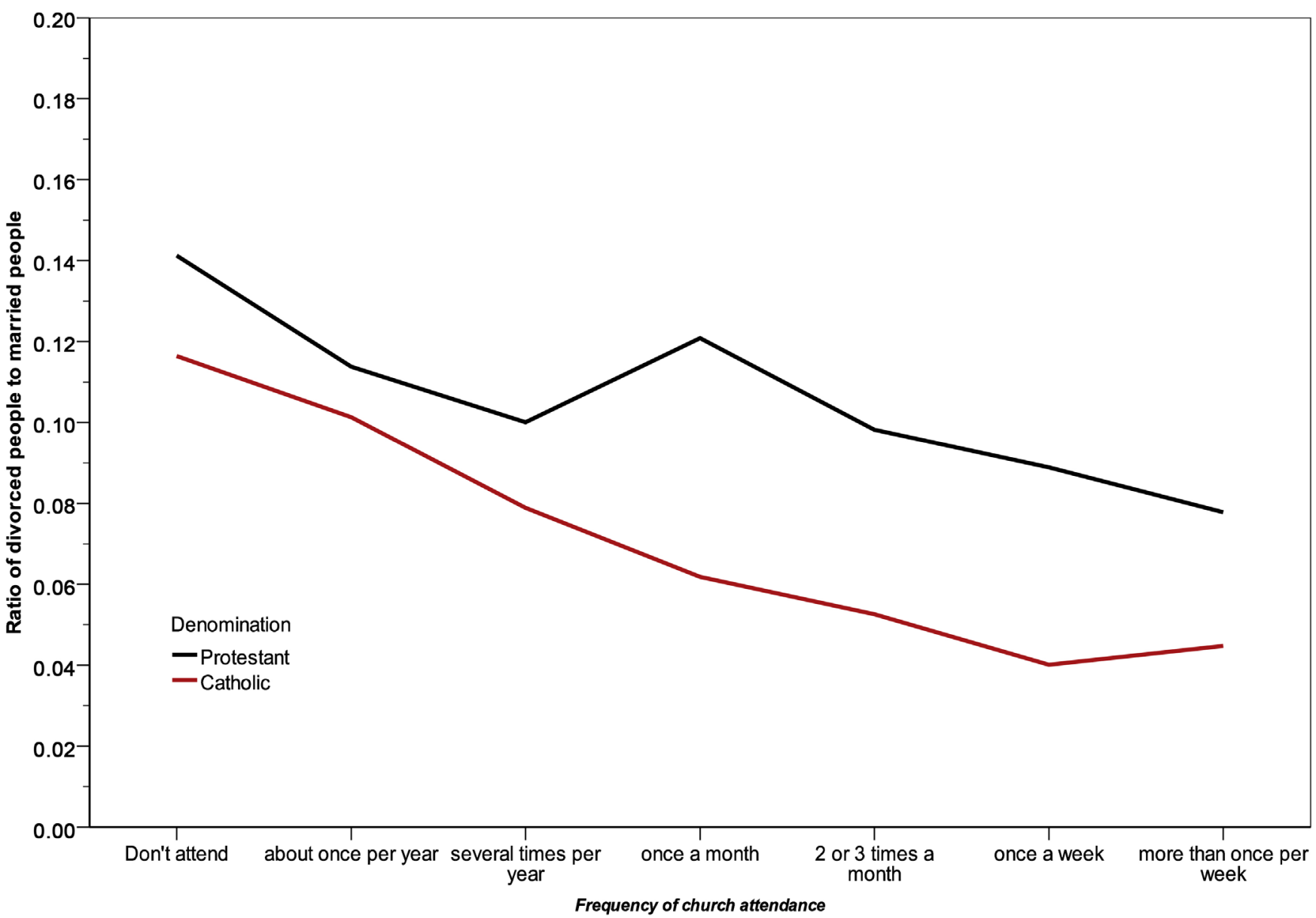

Figure 2. Divorce ratio, by frequency of church attendance and denomination. Source: ISSP, 1988 to 2015 (authors' analysis). 


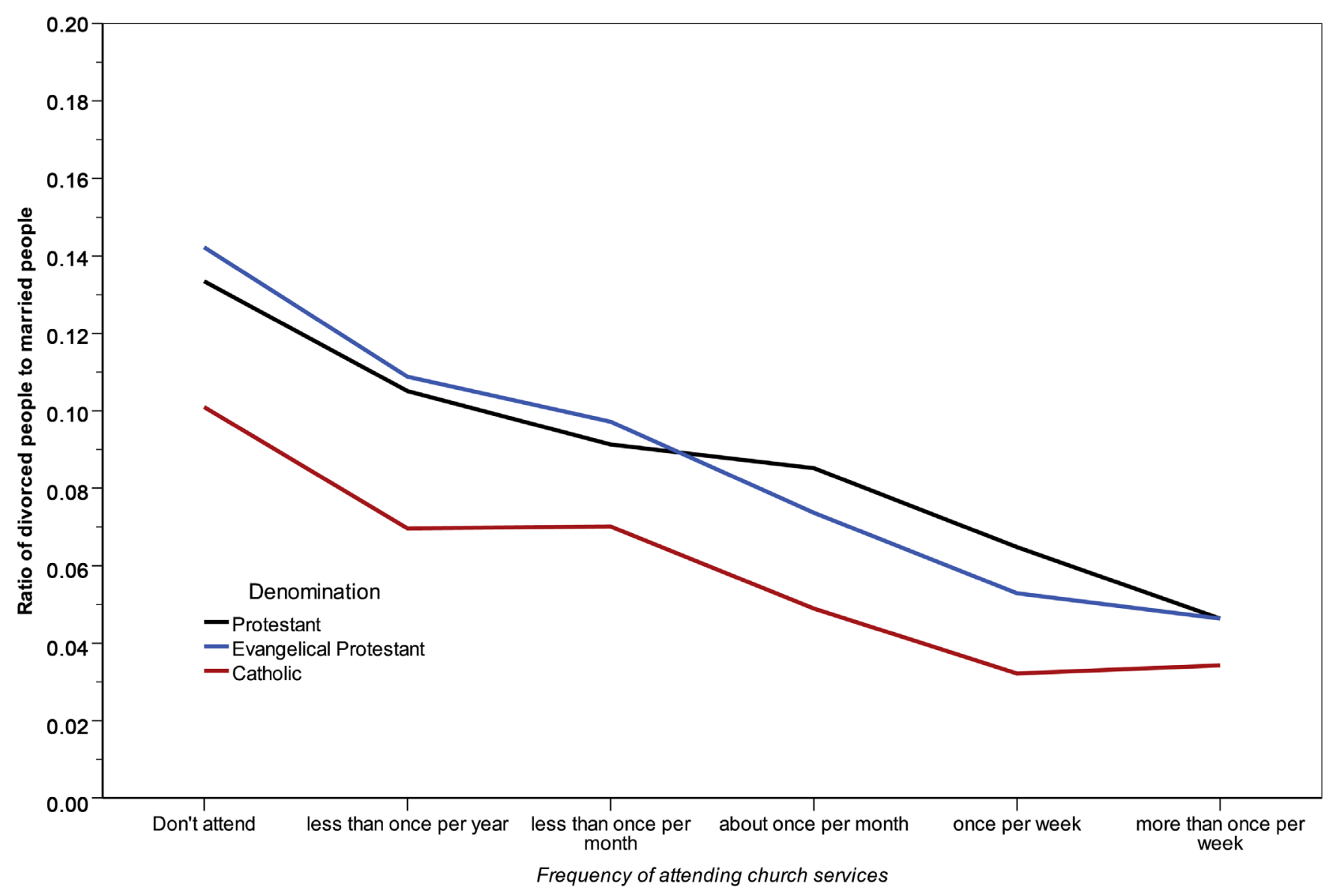

Figure 3. Divorce ratio, by frequency of church attendance and denomination. Source: EVS and WVS (authors' analysis).

Figure 4 helps us assess this possibility.

The horizontal axis of Figure 4 shows an attempt by the authors to estimate how much violence a female interview had experienced, as explained in the "data and methods" section. It is a crude estimate; but Figure 4 can be seen as evidence on the second hypothesis of this paper: that GBV is a reason for divorce. The increasing divorce-rate (from left to right) in Figure 4 is consistent with the hypothesis that some women divorce to avoid a violent husband.

Figure 4 also sheds light on whether Catholics are different from Protestants (evangelicals are excluded from Figure 4). The presence of children in the household appears to reduce divorce rates in Figure 4 ("children" defined as up to age 17); this paper doesn't attempt to control for all possible influences on divorce rates. Authors' analysis of DHS data (not reported here) indicates Catholics generally have more children than Protestants, perhaps due to the Catholic Church's ban on contraceptives. Whether we look at childless women (two dotted lines) or women with one or more children (two solid lines), divorce-rates tend to be lower for Catholics than Protestants in Figure 4; we could interpret this as Catholic women (in general) being more prepared than Protestants to tolerate GBV. This is explored further in Table 1, which suggests many Catholic women are prepared to accept some forms of GBV to preserve their marriage. 


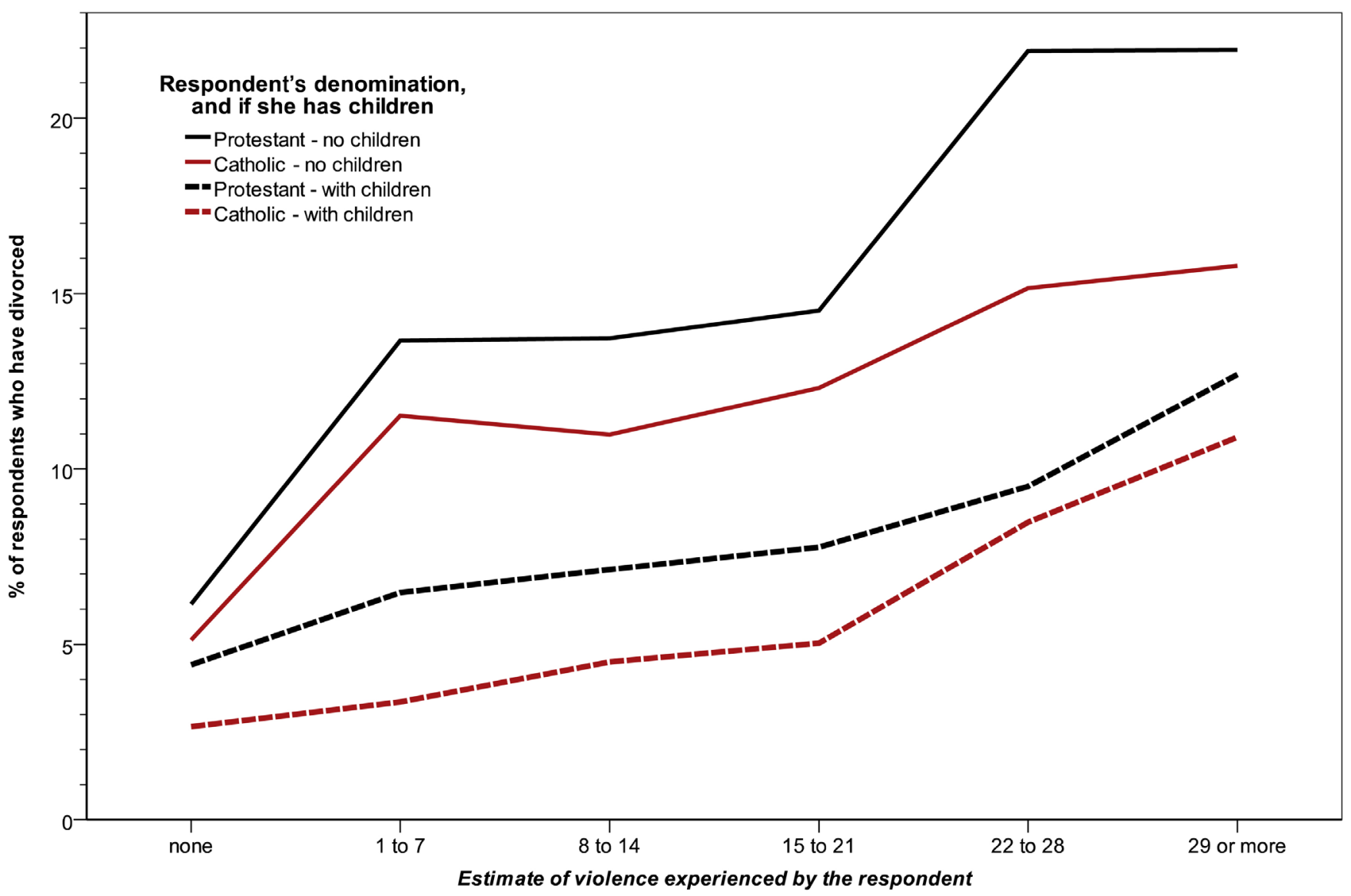

Figure 4. Divorce rates by experience of violence, denomination, and children. Source: DHS (authors' analysis).

Data in Table 1 are from EVS in 1981 to 1983; values may have changed since then. EVS surveys were only carried out in Europe. Table 1 shows Catholics far less likely than Protestants to accept divorce to avoid domestic violence: this applies to male and female respondents. Table 1 is consistent with the third hypothesis of this paper, that many Catholic women accept GBV because the Catholic Church forbids divorce.

Table 2 reports respondents' opinions about marital problems: ISSP asked if respondents agree or disagree that "It is better to have a bad marriage than no marriage at all". The authors exclude missing data; each row adds up to $100 \%$ (except rounding errors). Adding "strongly agree" \& "agree" columns, 9\% of Catholics consider a bad marriage better than divorce; whereas only $5 \%$ of Protestants strongly agree or agree ( $4 \%$ of evangelical Protestants strongly agree or agree). This question doesn't specifically mention domestic violence; but it seems consistent with the idea that marriage is more sacred to Catholics than to Protestants. Such attitudes could lead many Catholic women to remain in a violent marriage.

Table 3 reports one measure of GBV, to compare the prevalence of violence among Protestants and Catholics: whether the interviewee had visited a health facility due to violence from her husband. Some DHS surveys in Table A1 did not ask this question; for Table 3, the sample is restricted to women married at the time of interview, and 
Table 1. Attitudes to divorce for GBV, by religion and gender. Source: EVS 1981 to 1983; total sample 13,409 respondents.

\begin{tabular}{cccc}
\hline & $\begin{array}{c}\text { Respondent's attitude to } \\
\text { “Is domestic violence sufficient for divorce?" }\end{array}$ & Protestant & Catholic \\
\hline \multirow{2}{*}{ Male } & Respondent says violence is not sufficient for divorce & $19 \%$ & $35 \%$ \\
& Respondent says violence is sufficient for divorce & $81 \%$ & $65 \%$ \\
\multirow{2}{*}{ Female } & Total & $100 \%$ & $100 \%$ \\
& Respondent says violence is not sufficient for divorce & $14 \%$ & $32 \%$ \\
& Respondent says violence is sufficient for divorce & $86 \%$ & $68 \%$ \\
\hline
\end{tabular}

Table 2. Attitudes to "bad" marriage, by denomination and gender. Source: ISSP 1988, 1994, and 2002 .

\begin{tabular}{ccccccc}
\hline \multicolumn{5}{c}{ Dis/agreement with statement “A bad marriage is better than no marriage” } \\
\hline & $\begin{array}{c}\text { Strongly } \\
\text { agree }\end{array}$ & Agree & $\begin{array}{c}\text { Neither } \\
\text { agree or } \\
\text { disagree }\end{array}$ & Disagree & $\begin{array}{c}\text { Strongly } \\
\text { disagree }\end{array}$ & $\begin{array}{c}\text { Total } \\
\text { (number of cases })\end{array}$ \\
\hline Protestant & $2 \%$ & $3 \%$ & $6 \%$ & $36 \%$ & $54 \%$ & $100 \%(17,070)$ \\
Evangelical Protestant & $1 \%$ & $3 \%$ & $5 \%$ & $42 \%$ & $49 \%$ & $100 \%(3722)$ \\
Catholic & $2 \%$ & $7 \%$ & $6 \%$ & $40 \%$ & $44 \%$ & $100 \%(35,177)$ \\
\hline
\end{tabular}

Table 3. Visit to a medical facility by women, due to violence from their husband. Source: DHS (authors' analysis).

\begin{tabular}{|c|c|c|c|}
\hline Country & Denomination & $\begin{array}{l}\text { Fraction of respondents who visited } \\
\text { medical facility due to GBV }\end{array}$ & $\begin{array}{l}\text { Number of } \\
\text { respondents }\end{array}$ \\
\hline Burkina Faso & Catholic & $8.7 \%$ & 229 \\
\hline \multirow{2}{*}{ Cote D'Ivoire } & Protestant & $0.0 \%$ & 5 \\
\hline & Catholic & $8.8 \%$ & 57 \\
\hline \multirow{2}{*}{ Cameroon } & Protestant & $11.4 \%$ & 210 \\
\hline & Catholic & $13.3 \%$ & 218 \\
\hline $\begin{array}{c}\text { Dominican } \\
\text { Republic }\end{array}$ & Catholic & $11.4 \%$ & 79 \\
\hline \multirow{2}{*}{ Haiti } & Protestant & $1.0 \%$ & 614 \\
\hline & Catholic & $2.1 \%$ & 708 \\
\hline \multirow{2}{*}{ Kenya } & Protestant & $4.5 \%$ & 2076 \\
\hline & Catholic & $5.3 \%$ & 722 \\
\hline \multirow{2}{*}{ Malawi } & Protestant & $1.28 \%$ & 1012 \\
\hline & Catholic & $1.31 \%$ & 1217 \\
\hline \multirow{2}{*}{ Rwanda } & Protestant & $8.0 \%$ & 113 \\
\hline & Catholic & $7.2 \%$ & 207 \\
\hline \multirow{2}{*}{ Total } & Protestant & $3.6 \%$ & 4030 \\
\hline & Catholic & $4.3 \%$ & 3437 \\
\hline
\end{tabular}


who didn't report they ever divorced. The bottom two rows of Table 3 suggests Catholic women are more likely than Protestant women, to have visited a health facility because of GBV; but effective sample-sizes are not very large, and there are big differences between countries. Many women victims may choose not to visit a health facility, or may not be allowed to visit by their husband. Hence Table 3 provides some, limited, evidence that Catholic women experience more GBV than Protestant women.

\section{Discussion}

The problem of violence against women is often discussed; however, it is rare to discuss the implications of religion on domestic violence. In this paper, the authors draw attention to religious aspects of GBV-focusing on differences between Catholics and Protestants.

Religion could change the behaviour of men (e.g. making them less violent), or women (e.g. making them more likely to accept violence). Ellison, Bartkowski \& Anderson (1999) found that regular attendance at religious meetings is inversely associated with self-reported perpetration of domestic violence. Interestingly, men who are much more religious than their partners are especially likely to perpetrate domestic violence. Similarly, Ellison \& Anderson (2001) find regular religious attendance is associated with lower risk of GBV.

Evidence in this paper shows apparent differences between Catholics and Protestants. If religion does influence the risk of GBV, it is only one of many influences: for example, Table 3 suggests differences within a country (between Catholics and Protestants) are smaller than differences between countries. Future research could focus on one country. Some researchers might use regression to analyse possible GBV risk factors; other researchers may prefer a qualitative approach, such as focus groups. Researchers could focus on how to reduce GBV risk.

\section{Conclusions}

There is widespread agreement among medical professionals and academics that GBV is never justified. This paper sheds light on GBV, and possible effects of Catholicism. There are limits to how far surveys explain these complexities; for example, DHS data don't report if divorce was initiated by husband or wife. In-depth interviews can improve our understanding.

The Catholic Church prevention of divorce may keep millions of women in abusive marriages. USCCB (2002) reported a Catholic GBV victim's suffering: “unrelenting violence... unceasing pain. I shouldn't stay, but this is my husband [...] doesn't God hear me when I cry out silently as I lie in bed each night?" A victim can leave a violent husband, perhaps followed by annulment/divorce: leaving a violent husband doesn't prevent her from being a good Christian. If her congregation fails to support her, moving to a Protestant church may help. Many feminists are "lapsed" Catholics (Aune, 2011: p. 43); "Recent victories for women within religion-like winning the right to become Priests and Bishops in the Anglican Church-would probably not have oc- 
curred if feminists had not fought from within their religion for these changes" (Aune, 2011: p. 52).

Laws to prevent GBV can be strengthened by governments and international organisations, such as European Commission (2015). Latin American politicians "try to walk the line between accommodating the traditional power of the Catholic Church, complying with international agreements and scientific research, and discerning the position of their electorate" (Edgerton \& Sotirova, 2011: p. 41). The 2012 Council of Europe "Convention on preventing and combating violence against women and domestic violence" (Istanbul Convention) may help; but "the Catholic Church has officially declared itself against the ratification" (Szelewa, 2015: p. 20). Small grassroots women's organizations often help where governments fail-such as running self-esteem workshops, and providing counselling (Bystydzienski, 2001: p. 507). For example, Women's Aid in UK improved the lives of millions of GBV victims (European Institute for Gender Equality, 2008).

\section{Acknowledgements}

The authors are grateful to providers of survey data analysed in this paper, and agencies which paid for them. Eurobarometer and ISSP survey data are made available by GESIS Data Archive, Cologne, Germany; other survey data downloaded from their organisation's website. Views in this paper do not necessarily reflect opinions of organisations which commissioned the surveys.

\section{Author Contributions}

JS and GK developed the initial research idea together; JS carried out the initial dataprocessing; GK combined three tables produced by JS into a spreadsheet; JS produced more tables \& charts; GK produced most of the literature review; and JS carried out final editing.

\section{Conflicts of Interest}

The authors declare no conflict of interest.

\section{References}

Aizer, A. (2010). The Gender Wage Gap and Domestic Violence. American Economic Review, 100, 1847-1859. http://dx.doi.org/10.1257/aer.100.4.1847

Anderson, K. L. (1997). Gender, Status, and Domestic Violence: An Integration of Feminist and Family Violence Approaches. Journal of Marriage and Family, 59, 655-669. http://dx.doi.org/10.2307/353952

Aune, K. (2011). Much Less Religious, a Little More Spiritual: The Religious and Spiritual Views of Third-Wave Feminists in the UK. Feminist Review, 97, 32-55. http://dx.doi.org/10.1057/fr.2010.33

Bible Hub (2015). http://biblehub.com/matthew/5-32.htm

Bowlus, A. J., \& Seitz, S. (2006). Domestic Violence, Employment, and Divorce. International Economic Review, 47, 1113-1149. http://dx.doi.org/10.1111/j.1468-2354.2006.00408.x 
Brinkerhoff, M. B., Grandin, E., \& Lupri, E. (1992). Religious Involvement and Spousal Violence: The Canadian Case. Journal for the Scientific Study of Religion, 31, 15-31. http://dx.doi.org/10.2307/1386829

Burazeri, G., Roshi, E., Jewkes, R., Jordan, S., Bjegovic, V., \& Laaser, U. (2005). Factors Associated with Spousal Physical Violence in Albania: Cross Sectional Study. British Medical Journal, 331, 197-201. http://dx.doi.org/10.1136/bmj.331.7510.197

Bystydzienski, J. M. (2001). The Feminist Movement in Poland: Why So Slow? Women's Studies International Forum, 24, 501-511. http://dx.doi.org/10.1016/S0277-5395(01)00197-2

Cooper, L. B., Paluck, E. L., \& Fletcher, E. K. (2013). Reducing Gender-Based Violence. In M. K. Ryan, \& N. R. Branscombe (Eds.), The SAGE Handbook of Gender and Psychology (pp. 359-377). London: Sage. http://dx.doi.org/10.4135/9781446269930.n22

Duby, G. (1999). History of Private Life. In G. Duby, \& P. Aries (Eds.), From Feudal Europe to the Renaissance (2nd ed., Vol. 2). Wrocław: Ossolineum.

Dutton, M. A. (2009). Update of the "Battered Woman Syndrome" Critique. Harrisburg, PA: VAWnet: A Project of the National Resource Center on Domestic Violence/Pennsylvania Coalition against Domestic Violence.

http://vawnet.org/applied-research-papers/print-document.php?doc_id=2061

Edgerton, A., \& Sotirova, I. (2011). Sex and the Barrio: A Clash of Faith in Latin America. World Policy Journal, 28, 34-41.

Ellison, C. G., \& Anderson, K. L. (2001). Religious Involvement and Domestic Violence among US Couples. Journal for the Scientific Study of Religion, 40, 269-286.

http://dx.doi.org/10.1111/0021-8294.00055

Ellison, C. G., Wolfinger, N. H., \& Ramos-Wada, A. I. (2011). Attitudes toward Marriage and Cohabitation among Working-Age Latinos: Does Religion Matter? 2011 Annual Meeting of the Population Association of America (pp. 1-38), Washington DC: World Population Program. http://paa2011.princeton.edu/papers/112269

Ellison, C. G., Bartkowski, J. P., \& Anderson, K. L. (1999). Are There Religious Variations in Domestic Violence? Journal of Family Issues, 20, 87-113. http://dx.doi.org/10.1177/019251399020001005

Ellsberg, M., \& Heise, L. (2005). Researching Violence against Women: A Practical Guide for Researchers and Activists. Washington DC: World Health Organization, PATH.

European Commission (2008). Eurobarometer 69.1. February-March 2008. TNS Opinion \& Social, ZA4743 Dataset Version 3.0.0, Brussels: GESIS Data Archive.

European Commission (2015). Zero Tolerance of Violence against Women. http://ec.europa.eu/justice/gender-equality/gender-violence/index_en.htm

European Institute for Gender Equality (2008). The Power to Change-How to Set up and Run Support Groups for Victims and Survivors of Domestic Violence.

http://eige.europa.eu/gender-based-violence/resources/estonia/power-change-how-set-and-ru n-support-groups-victims-and-survivors-domestic-violence

EVS (2011). European Values Study Longitudinal Data File 1981-2008 (EVS 1981-2008). ZA4804 Data file Version 2.0.0, Cologne: GESIS Data Archive.

Foss, L. L., \& Warnke, M. A. (2003). Fundamental Protestant Christian Women: Recognizing Cultural and Gender Influences on Domestic Violence. Counselling and Values, 48, 14-23. http://dx.doi.org/10.1002/j.2161-007X.2003.tb00271.x

Fox, V. C. (2002). Historical Perspectives on Violence against Women. Journal of International Women's Studies, 4, 15-34. 
GESIS (2015). ISSP - The International Social Survey Programme.

http://zacat.gesis.org/webview/index.jsp?object=http://zacat.gesis.org/obj/fCatalog/Catalog5

Hanson, D. W. (1993). Battered Women: Society's Obligation to the Abused. Akron Law Review, $27,19-56$

Holy See (1993). Catechism of the Catholic Church. www.vatican.va/archive/ENG0015/_P57.htm

ISSP (2015). History of the ISSP. International Social Survey Program. www.issp.org/page.php?pageId=216

Jolly, M. (2012). Engendering Violence in Papua New Guinea: Persons, Power and Perilous Transformations. In M. Jolly, C. Stewart, \& C. Brewer (Eds.), Engendering Violence in Papua New Guinea (pp. 1-31). Canberra: Australian National University Press.

Knoblock, J. (2008). Gender and Violence: A Reflective Sociology of How Gender Ideologies and Practices Contribute to Gender Based Violence. Human Architecture: Journal of the Sociology of Self-Knowledge, 6, 91-101.

Lehrer, E., Lehrer, V., \& Krauss, R. (2009). Religion and Intimate Partner Violence in Chile: Macro- and Micro-Level Influences. Association of Religion Data Archives, Park: Pennsylvania State University. www.thearda.com/asrec/archive/papers/Lehrer\%20-\%20Religion\%20and\%20Intimate\%20Part ner\%20Violence\%20in\%20Chile\%20-\%20ASREC09.doc

Lew-Starowicz, Z. (1992). Przemoc Seksualna (pp. 50-52). Warszawa: Santorski \& Co Agencja Wydawnicza.

Marks, L. (2006). Religion and Family Relational Health: An Overview and Conceptual Model. Journal of Religion and Health, 45, 603-618. http://dx.doi.org/10.1007/s10943-006-9064-3

National Population Commission \& ICF International (2014). Nigeria Demographic and Health Survey 2013. Abuja: NPC and ICF International. http://dhsprogram.com/publications/publication-FR293-DHS-Final-Reports.cfm

National Population Commission \& ICF Macro (2009). Nigeria Demographic and Health Survey 2008. Abuja: National Population Commission and ICF Macro. http://dhsprogram.com/publications/publication-FR222-DHS-Final-Reports.cfm

Sharp, S. (2009). Escaping Symbolic Entrapment, Maintaining Social Identities. Social Problems, 56, 267-284. http://dx.doi.org/10.1525/sp.2009.56.2.267

Simister, J. (2012). More than a Billion Women Face "Gender Based Violence" Where Are Most Victims? Journal of Family Violence, 27, 607-623. http://dx.doi.org/10.1007/s10896-012-9457-x

Slabu, E. (2014). Family Violence-Theoretical and Practical Aspects. Public Administration \& Regional Studies, 1, 49-60.

Szelewa, D. (2015). The Policy on Gender Equality in Poland-Update 2015. European Parliament Directorate General for Internal Policies, Policy Department C: Citizens' Rights and Constitutional Affairs, Women's Rights \& Gender Equality. www.europarl.europa.eu/RegData/etudes/IDAN/2015/510023/IPOL_IDA(2015)510023_EN.pdf

Uganda Bureau of Statistics \& ICF International Inc (2012). Uganda Demographic and Health Survey 2011. Kampala: UBOS and Calverton, Maryland: ICF International Inc.

https://dhsprogram.com/pubs/pdf/FR264/FR264.pdf

UN Women (2016). Facts and Figures: Ending Violence against Women. www.unwomen.org/en/what-we-do/ending-violence-against-women/facts-and-figures\#notes

USCCB (2002). When I Call for Help: A Pastoral Response to Domestic Violence against 
Women. Women in Society and in the Church and the Committee on Marriage and Family of the United States Conference of Catholic Bishops.

www.usccb.org/issues-and-action/marriage-and-family/marriage/domestic-violence/when-i-ca ll-for-help.cfm

Watts, C., \& Zimmerman, C. (2002). Violence against Women: Global Scope and Magnitude. The Lancet, 359, 1232-1237. http://dx.doi.org/10.1016/S0140-6736(02)08221-1

Webb, A. P. (2008). A Religious Coping Model of Divorce Adjustment. PhD Thesis, Austin, TX: University of Texas. https://repositories.lib.utexas.edu/handle/2152/18245

WHO (2013). Global and Regional Estimates of Violence against Women: Prevalence and Health Effects of Intimate Partner Violence and Non-Partner Sexual Violence. World Health Organization. http://apps.who.int/iris/bitstream/10665/85239/1/9789241564625_eng.pdf

Wojnicka, K. (2015). Work with Perpetrators of Domestic Violence in Eastern European and Baltic Countries. Gender, Rovné Př́ležitosti, Vyzkum, 16, 35-45.

http://dx.doi.org/10.13060/12130028.2015.16.1.165

WVS (2015a). Who We Are. World Values Survey. www.worldvaluessurvey.org/WVSContents.jsp

WVS (2015b). World Values Survey 1981-2014 Longitudinal Aggregate. World Values Survey Association, Madrid: JD Systems. www.worldvaluessurvey.org

Yodanis, C. (2005). Divorce Culture and Marital Gender Equality: A Cross-National Study. Gender and Society, 19, 644-659. http://dx.doi.org/10.1177/0891243205278166 


\section{Appendix}

Table A1 shows the effective sample sizes, in the four figures in this paper. Samples are small in some countries, because Figures 1-4 are limited to Catholic or Protestant respondents (and evangelical Christians, in Figure 3).

Table A1. Sample sizes for Figure 1 (EB data), Figure 2 (ISSP data), Figure 3 (EVS/ WVS data), and Figure 4 (DHS data).

\begin{tabular}{|c|c|c|c|c|}
\hline \multirow{2}{*}{ Country } & \multicolumn{4}{|c|}{ Survey } \\
\hline & EB & ISSP & EVS/WVS & DHS \\
\hline Albania & 0 & 0 & 681 & 0 \\
\hline Algeria & 0 & 0 & 4 & 0 \\
\hline Andorra & 0 & 0 & 285 & 0 \\
\hline Argentina & 0 & 1997 & 2402 & 0 \\
\hline Armenia & 0 & 0 & 14 & 0 \\
\hline Australia & 0 & 15,263 & 1985 & 0 \\
\hline Austria & 4291 & 10,777 & 2392 & 0 \\
\hline Azerbaijan & 0 & 0 & 7 & 0 \\
\hline Bangladesh & 0 & 4 & 18 & 0 \\
\hline Belarus & 0 & 0 & 375 & 0 \\
\hline Belgium & 3912 & 5023 & 3117 & 0 \\
\hline Bosnia \& Herzegovina & 0 & 0 & 302 & 0 \\
\hline Brazil & 0 & 2155 & 1864 & 0 \\
\hline Bulgaria & 92 & 132 & 35 & 0 \\
\hline Burkina Faso & 0 & 0 & 317 & 1881 \\
\hline Cameroon & 0 & 0 & 0 & 1063 \\
\hline Canada & 0 & 6352 & 2971 & 0 \\
\hline Chile & 0 & 9300 & 2349 & 0 \\
\hline China & 0 & 254 & 178 & 0 \\
\hline Chinese Taipei & 0 & 808 & 111 & 0 \\
\hline Colombia & 0 & 0 & 2326 & 0 \\
\hline Cote D'Ivoire & 0 & 0 & 0 & 436 \\
\hline Croatia & 3716 & 4859 & 1858 & 0 \\
\hline Cyprus & 43 & 37 & 16 & 0 \\
\hline Czech Republic & 1864 & 7504 & 2024 & 0 \\
\hline Dem Rep of the Congo & 0 & 0 & 0 & 1333 \\
\hline Denmark & 3868 & 10893 & 2598 & 0 \\
\hline Dominican Republic & 0 & 2480 & 107 & 1358 \\
\hline East Timor & 0 & 0 & 0 & 2028 \\
\hline Ecuador & 0 & 0 & 397 & 0 \\
\hline Egypt & 0 & 0 & 259 & 0 \\
\hline
\end{tabular}




\section{Continued}

\begin{tabular}{|c|c|c|c|c|}
\hline El Salvador & 0 & 0 & 428 & 0 \\
\hline Estonia & 1294 & 222 & 314 & 0 \\
\hline Ethiopia & 0 & 0 & 140 & 0 \\
\hline Finland & 4045 & 8592 & 2758 & 0 \\
\hline France & 3214 & 11,480 & 2219 & 0 \\
\hline Georgia & 0 & 13 & 31 & 0 \\
\hline Germany & 4965 & 16,816 & 5464 & 0 \\
\hline Ghana & 0 & 0 & 1058 & 272 \\
\hline Greece & 40 & 0 & 20 & 0 \\
\hline Guatemala & 0 & 0 & 413 & 0 \\
\hline Haiti & 0 & 0 & 0 & 2786 \\
\hline Hong Kong (China) & 0 & 0 & 187 & 0 \\
\hline Hungary & 3100 & 13,454 & 2412 & 0 \\
\hline Iceland & 376 & 1715 & 1779 & 0 \\
\hline India & 0 & 56 & 262 & 0 \\
\hline Indonesia & 0 & 0 & 18 & 0 \\
\hline Iran & 0 & 0 & 8 & 0 \\
\hline Iraq & 0 & 0 & 17 & 0 \\
\hline Ireland & 4345 & 12,097 & 2182 & 0 \\
\hline Israel & 0 & 231 & 0 & 0 \\
\hline Italy & 4453 & 8863 & 3995 & 0 \\
\hline Japan & 0 & 44 & 80 & 0 \\
\hline Jordan & 0 & 0 & 52 & 0 \\
\hline Kazakhstan & 0 & 0 & 18 & 0 \\
\hline Kenya & 0 & 0 & 0 & 6386 \\
\hline Kyrgyzstan & 0 & 0 & 16 & 0 \\
\hline Latvia & 2323 & 3952 & 1021 & 0 \\
\hline Lebanon & 0 & 0 & 147 & 0 \\
\hline Lithuania & 3673 & 1950 & 1861 & 0 \\
\hline Luxembourg & 2257 & 0 & 1074 & 0 \\
\hline Macedonia & 0 & 0 & 19 & 0 \\
\hline Malawi & 0 & 0 & 0 & 4094 \\
\hline Malaysia & 0 & 0 & 139 & 0 \\
\hline Mali & 0 & 0 & 20 & 73 \\
\hline Malta & 2302 & 0 & 2091 & 0 \\
\hline Mexico & 0 & 6259 & 4664 & 0 \\
\hline Moldova & 0 & 0 & 62 & 123 \\
\hline Montenegro & 0 & 0 & 88 & 0 \\
\hline Netherlands & 2753 & 7400 & 2176 & 0 \\
\hline
\end{tabular}


Continued

\begin{tabular}{|c|c|c|c|c|}
\hline New Zealand & 0 & 7186 & 1264 & 0 \\
\hline Nigeria & 0 & 0 & 1864 & 16,521 \\
\hline Norway & 739 & 19,667 & 2921 & 0 \\
\hline Palestinian Territory & 0 & 0 & 1 & 0 \\
\hline Peru & 0 & 0 & 1909 & 0 \\
\hline Philippines & 0 & 16,832 & 1982 & 4443 \\
\hline Poland & 4030 & 14,530 & 4124 & 0 \\
\hline Portugal & 4769 & 10,238 & 2018 & 0 \\
\hline Puerto Rico & 0 & 0 & 859 & 0 \\
\hline Romania & 385 & 0 & 506 & 0 \\
\hline Russia & 0 & 103 & 55 & 0 \\
\hline Rwanda & 0 & 0 & 1200 & 3181 \\
\hline Sao Tome \& Principe & 0 & 0 & 0 & 123 \\
\hline Saudi Arabia & 0 & 0 & 19 & 0 \\
\hline Serbia & 0 & 0 & 239 & 0 \\
\hline Singapore & 0 & 0 & 326 & 0 \\
\hline Slovakia & 4262 & 7768 & 2990 & 0 \\
\hline Slovenia & 2878 & 10,380 & 2723 & 0 \\
\hline South Africa & 0 & 5903 & 3728 & 0 \\
\hline South Korea & 0 & 3502 & 1511 & 0 \\
\hline Spain & 3816 & 18,072 & 7063 & 0 \\
\hline Sweden & 3138 & 10,471 & 3209 & 0 \\
\hline Switzerland & 1108 & 10,686 & 2612 & 0 \\
\hline Tanzania & 0 & 0 & 299 & 0 \\
\hline Thailand & 0 & 0 & 7 & 0 \\
\hline Trinidad \& Tobago & 0 & 0 & 439 & 0 \\
\hline Turkey & 5 & 6 & 22 & 0 \\
\hline Uganda & 0 & 0 & 286 & 1532 \\
\hline UK & 4256 & 12,209 & 3427 & 0 \\
\hline Ukraine & 0 & 264 & 424 & 134 \\
\hline Uruguay & 0 & 1794 & 675 & 0 \\
\hline USA & 0 & 14,331 & 4438 & 0 \\
\hline Uzbekistan & 0 & 0 & 3 & 0 \\
\hline Venezuela & 0 & 1747 & 887 & 0 \\
\hline Vietnam & 0 & 0 & 135 & 0 \\
\hline Zambia & 0 & 0 & 434 & 3838 \\
\hline Zimbabwe & 0 & 0 & 1100 & 2474 \\
\hline TOTAL & 86,312 & 336,671 & 121,924 & 54,079 \\
\hline
\end{tabular}


Submit or recommend next manuscript to SCIRP and we will provide best service for you:

Accepting pre-submission inquiries through Email, Facebook, LinkedIn, Twitter, etc. A wide selection of journals (inclusive of 9 subjects, more than 200 journals)

Providing 24-hour high-quality service

User-friendly online submission system

Fair and swift peer-review system

Efficient typesetting and proofreading procedure

Display of the result of downloads and visits, as well as the number of cited articles

Maximum dissemination of your research work

Submit your manuscript at: http://papersubmission.scirp.org/

Or contact psych@scirp.org 